\title{
"An Unacceptable Surrender of Fiscal Sovereignty": The Neoliberal Turn to International Tax Arbitration
}

\author{
Martin Hearson and Todd N. Tucker
}

\begin{abstract}
The growth of inequality over the past half century is closely connected to the rise of neoliberal policies and institutions, the latter of which shield capital from state actions that might limit wealth accumulation. Economic nationalism since the global financial crisis has slowed or even reversed this, yet this same era has seen the emergence of a new form of instrument in the neoliberal mold, in a stronghold of state sovereignty: taxation. Under mandatory binding tax arbitration, states cede sovereignty over the interpretation of international tax agreements to panels of transnational tax adjudicators. Focusing on the pivotal role of the United States, we use historical documents, including from the congressional archive and interviews with key actors to ask why tax arbitration emerged late in the neoliberal era, and at a counterintuitive time. We demonstrate that this outcome is the result of instrumental business power driving a process of incremental change through layering, to overcome states' preference to retain sovereignty. This experience sheds light on the historically structured ways that business power constrains sovereignty in an era of high inequality.
\end{abstract}

From [the business] point of view ... a binding arbitration system would have a number of important advantages ... [but] the adoption of such a procedure would represent an unacceptable surrender of fiscal sovereignty.

—OECD Committee on Fiscal Affairs, 1984

A list of permanent links to Supplemental Materials provided by the authors precedes the References section.

Martin Hearson (1) is a Research Fellow at the Institute of Development Studies, where he is International Tax Programme Lead for the International Centre for Tax and Development (ICTD) (m.hearson@ids.ac.uk). His research focuses on the politics of international business taxation, and in particular the relationship between developed and developing countries. He is author of Imposing Standards: The North-South Politics of Global Tax Governance (Cornell University Press, 2021).

\section{Todd N. Tucker is a Political Scientist and Director of Governance Studies at the Roosevelt Institute, where he helps lead research on global governance, democracy, and the administrative state as part of the Climate and Economic Transformation team (ttucker@rooseveltinstitute.org). He is author of Judge Knot: Politics and Development in International Investment Law (Anthem Press, 2018). Prior to his doctoral work, he led research on international issues for Public Citizen and worked as an analyst at other think tanks.}

We are about to make tax treaty history! Before you lies the first ever multilateral instrument capable of amending bilateral tax treaties ... [This is] the largest, and fastest, rewriting of the international tax rules in a century ... [it] gives you the tools needed to implement mandatory binding arbitration.

—Angel Gurria, OECD Secretary General, 2017

$T$ he growth of inequality over the past half century is closely connected to the rise of neoliberal policies and institutions, the latter of which shield capital from state actions that might limit wealth accumulation. Economic nationalism since the global financial crisis has slowed or even reversed this, yet this same era has seen the emergence of a new form of instrument in the neoliberal mold, in a stronghold of state sovereignty: taxation. Under mandatory binding tax arbitration, states cede sovereignty over the interpretation of international tax agreements to panels of transnational tax adjudicators. Focusing on the pivotal role of the United States, we use historical documents, including from the congressional archive and interviews with key actors to ask why tax arbitration emerged late in the neoliberal era, and at a counterintuitive time. We demonstrate that this outcome is the result of instrumental business power driving a process of incremental change through layering, to overcome states' preference to retain sovereignty. This experience sheds light on the historically structured ways that business power constrains sovereignty in an era of high inequality. 
We are in the midst of a quiet revolution in the governance of corporate taxation. At a time when economic nationalism is undermining longstanding institutions of international cooperation, states are increasingly ceding sovereignty over the interpretation of international tax agreements from domestic courts to panels of transnational tax adjudicators. Nowhere is this change more stark than in the United States, which opposed international tax arbitration until the mid-2000s, but now embraces it so enthusiastically that it has made it an essential quid pro quo if foreign governments are to have greater tax jurisdiction over U.S. digital firms (Bulusu and Ali 2019). This development is consistent with a trend across global governance in recent decades through which states enter into enforceable, sovereignty-constraining and pro-capital commitments. Yet the timing is a puzzle, at a moment when such institutions are meeting resistance from economic nationalism. Furthermore, the international tax regime is generally characterized as strongly resistant to such radical encroachment on sovereignty. We reconcile these contradictions by focusing on how advocates of neoliberal reform pursue change incrementally.

For over a decade, multinational enterprises (MNEs) operating in the United States and Canada have been able to use binding international arbitration panels to overturn tax assessments raised by the Internal Revenue Service (IRS) and its Canadian equivalent. In 2017, more than two dozen countries agreed to adopt similar rules into their bilateral tax treaties. Non-state private adjudicators are now empowered to issue binding opinions settling thorny distributional questions about which countries get to tax which bit of multinational capital and by how much. This transfer of power away from states was not accomplished through deeply integrated regional bodies such as the European Union-which has itself had an ambivalent relationship with tax arbitration-but through the decentralized regime for global taxation built around the OECD. The countries now signed up to the arbitration standard span multiple continents and many, such as the United States and Japan, had previously opposed it.

This is, on the face of it, a familiar story of a neoliberal capitalist order that gives transnational capital ever more rights over states. Constraints on states' ability to tax MNEs can be seen as part and parcel of a political economic framework designed to "encase" markets, shielding them from the vagaries of national democratic politics (Gill 1998; Slobodian 2018). Indeed, arbitration forms part of a new discourse of "tax certainty" that seems precisely to reflect this trend (IMF and OECD 2017). In other economic policy areas, states have for decades opened themselves up to transnational adjudication. Through investor-state dispute settlement, they allow private companies to sue them outside of national courts over a wide range of domestic environmental, health, and other policies (Tucker 2018). Similar litigation risks are present in the state-to-state proceedings at the World Trade Organization (Davis 2009). And a wide range of regional and subject-specific courts now monitor states' activity behind and within national borders (Alter, Hafner-Burton, and Helfer 2019).

We contend that the encroachment of neoliberalism into matters of corporate taxation operates differently. For a start, the timing of this move is counterintuitive. It coincides with an era of popular outrage at inequality in the wake of the 2007-2009 financial crisis (Boushey 2019; Saez and Zucman 2019). Chief among these grievances is the unfairness of an economic system that allowed wealthy corporations and elites to pay little to no tax. Social movements, journalists, and legislators have brought attention to particularly egregious tax avoidance practices by technology firms such as Google and Amazon and the details of massive data leaks like the Panama Papers (Vaughan 2019). Governments responded at first with intensified cooperation to tackle tax avoidance and evasion, but more recently many have instituted new unilateral taxes that respond to popular pressure but risk the integrity of the century-old institutions of global tax cooperation (Christensen and Hearson 2019; Mason 2020). Thus, economic nationalism is jeopardizing global tax cooperation, just as it has the World Trade Organization and European Union. This seems like an odd time to be giving transnational actors more enforceable rights over states.

Furthermore, the post-crisis outcry over tax avoidance reinforces a longstanding sentiment that taxation is special, the last bastion of unencumbered state sovereignty. New constitutionalism, a concept closely related to neoliberalism, draws an analogy with the logic of liberal democracies, in which the constitution is designed to protect minority groups from the "tyranny of the majority" (Gill 1998). Thus, in the global political economy, new constitutionalism shields capital from the impact of democratic politics. This sits uneasily with taxation, which is seen to be at the heart of the emergence and practice of democratic rule (Goldscheid 1958; Schumpeter 1918; Tilly 1992). This is one explanation for why international governance institutions in the area of taxation entail significantly less pooling of sovereignty than others: many scholars have argued that the growth of tax havens in recent decades was due to states being unable or unwilling to build an international regime that impinged on their autonomy over fiscal affairs (Palan 2003; Rixen 2011; Sharman 2006).

We seek to understand how the transnational neoliberal project has encroached into an area of policy_international taxation - that had previously seemed immune. To gain a granular picture of U.S. and international political dynamics, we read dozens of congressional committee hearings from 1918 to the present. We supplemented these with historical documents drawn from other governmental archives, and with specialist media reports. We also conducted 
interviews and informal discussions with thirteen individuals who had been involved in tax arbitrations or the negotiation of arbitration provisions. ${ }^{2}$

Building on the business power literature, we demonstrate a decades-long incremental exercise of instrumental and discursive power that persuaded states to accept an institutional change they had long resisted, which bore fruit at a moment when it was least expected. Because businesses' interests are served by global cooperation, rather than pure competition, their structural power through capital markets was too blunt a tool to achieve this on its own. Meanwhile, states' attitude towards tax arbitration must be understood in the context of its ambiguous relationship with sovereignty preservation, because arbitration is simultaneously a loss of judicial sovereignty and a means of reinforcing other sovereignty-preserving elements of a regime.

Our analysis contributes to historical institutionalist scholarship by demonstrating how processes of layering can take place under the surface, leading to changes in the observable policy environment at unexpected moments. In particular, when businesses can sell major reforms as reversible experiments that may make it easier for a given regime to deliver on its original mandate, the stakes in entering into non-binding judicialization can seem lower. Then, when the experiment generates problems of its own, calls for a rationalization and more efficient dispute resolution can seem like commonsensical solutions-rather than the power shifts they are. These pathways towards least likely outcomes can serve as warning signs for governments at a time of pandemic and economic crisis that may fundamentally reshape governance institutions in lasting ways.

\section{Neoliberalism and the Taxation of Multinational Companies}

When we think of corporate tax policy in the neoliberal era, typically we think of a "race to the bottom" over tax rates. Some contributions to political science literature explicitly operationalize it in this way (Hakelberg and Rixen forthcoming; Swank 2006). For sure, the neoliberal era has profoundly affected the politics of the tax state, in line with the "Washington Consensus" prescription of lower rates and broader bases (Williamson 1990). The tax systems of Western states have become less redistributive than in the Bretton Woods era (Saez and Zucman 2019). Nonetheless, tax competition literature finds that domestic social and political factors, such as longstanding norms and political partisanship, act as scope conditions for the strategic interaction between states (Basinger and Hallerberg 2004; Jensen and Lindstadt 2012; Plümper, Troeger, and Winner 2009; Swank 2006). Since the financial crisis of 2007-2009, the race to the bottom among OECD member states has slowed as these countervailing pressures have intensified, and states have begun to work together to tackle tax avoidance and evasion (Hakelberg and Rixen forthcoming).

But neither neoliberalism nor the politics of corporate taxation can be reduced to structural power. We refer to neoliberalism here in the sense described by Quinn Slobodian (2018), as the creation of a web of global institutions that "encases" global markets, including for direct and portfolio investment. This requires the creation by states of a particular type of strong institution, which protects markets from interference by national-level democratic politics-those "countervailing pressures" against tax competition:

The real focus of neoliberal proposals is not on the market per se but on redesigning states, laws, and other institutions to protect the market... What neoliberals seek is not a partial but a complete protection of private capital rights, and the ability of supranational judiciary bodies like the European Court of Justice and the WTO to override national legislation that might disrupt the global rights of capital. (6-15)

This view of neoliberal globalization has much in common with the literature on "new constitutionalism," under which governments have agreed to be bound by rules that "confer privileged rights to citizenship and representation on corporate capital and large investors," (Gill 1998, 23). This literature emphasizes the emergence since the 1980s of a "de facto constitutional governance structure for the world market" accompanied by "specific locking-in mechanisms" that make it harder for states to undo their institutional commitments (Gill and Cutler 2014, 7). As David Schneiderman describes, "rules for the protection of FDI [Foreign Direct Investment] have emerged as ... an important component of the new constitutionalism to protect the interests of capital" (Schneiderman 2000, 759).

Long before they worked together on tax avoidance and evasion, states were cooperating to create just such rules. While tax rates are important to investors, in practice a mix of legislative, administrative, and judicial elements contribute to the tax environment (see for example Maffini 2015). Stability and cross-jurisdictional consistency, in all three branches of government, can be as important to investors as the tax rate (IMF and OECD 2017).

Recognizing this, states have created a regime based on two instruments: transfer pricing rules and tax treaties. Both have diffused widely, in part a product of tax competition (Barthel and Neumayer 2012; Eden, Dacin, and Wan 2001; Hearson 2021). Transfer pricing rules dictate how the profits of multinational firms are attributed to the countries in which they operate. Firms are treated as collections of separate affiliates, trading with each other at free market prices (the "arm's length principle"). Transfer pricing is a matter for sovereign domestic tax law, but in practice national rules are highly standardized because most countries adhere to the OECD's Transfer Pricing Guidelines. Bilateral tax 
treaties, for their part, are legally binding agreements that divide taxing rights over cross-border economic activity. They are heavily influenced by OECD and UN templates, but states retain the right to decide with whom they conclude treaties, and on what terms.

The global regime for corporate taxation is thus an incomplete constitutional project: a patchwork of agreements that create standardized, enforceable rights for transnational capital, while preserving sovereign autonomy over most aspects of tax systems. One key aspect of this autonomy is over the interpretation of domestic and international rules, which continue to be enforced by domestic courts. Taxpayers frequently disagree with revenue authorities' assessments of their tax liability-for example with the value of a transfer price or with the characterization of transaction by reference to treaty provisions. Worse still for MNEs, if two countries' revenue authorities apply treaty or transfer pricing rules differently, they may face "double taxation," an overlapping claim to tax the same income from both countries concerned. In such cases, the taxpayer can challenge the assessment, but only through national courts. Disputes over the interpretation of tax treaties and transfer pricing rules are a huge area of tax law throughout the OECD and G20 (Baistrocchi 2017).

One drawback of enforcing international agreements in domestic courts is that the court is only concerned with the tax laws of its own country, not with the interactions between different states' tax systems that create double taxation (Christians 2011). Nor can it force a foreign revenue authority to agree. Tax treaties contain an instrument to fix this, the mutual agreement procedure (MAP). MAP is a "semi-diplomatic" process to resolve individual disputes on the application of a treaty (French Tax Administration 2017). Where revenue authorities disagree, it allows the affected taxpayer to force their "competent authorities" to the negotiating table. It is a soft tool to discipline states. According to John Harrington, a U.S. Treasury official:

Typically, a dispute under the tax treaty comes up because the taxpayer has determined that one of the governments isn't taxing consistently with the treaty. So, it goes to the competent authority. In the United States, the U.S. taxpayer is going to typically go to the U.S. competent authority and say, "This other country isn't engaging properly.” (U.S. Congress 2007, 33-34)

As one partner in a tax law firm in an OECD country explained, in a recent case they had filed for MAP through a treaty partner, "to try to force [this country] to see sense. We're using MAP as a tactic to force [the tax authority] to be more reasonable" (Interview 5).

But until the developments explored in this article, businesses' rights ended there. They could not force either state to agree. States retained the ultimate right of their judicial and executive branches to interpret their international obligations. It is a common complaint from businesses that governments' participation in MAPs is not in good faith. They can reject requests to commence MAP discussions, and enter into "package deals," where individual cases are traded off against each other rather than treated individually (Clayson, Snodgrass, and Young 2017). Some countries are seen as more liable to frustrate resolution than others: fingers are often pointed at procedural obstacles in Italy, and the German practice of threatening firms with a greater tax bill if they trigger a MAP (Interview 9; Hyde and Thomas 2016). A list of complaints from businesses in 2015 includes that "competent authorities demonstrate little willingness to compromise," and "some countries have also allowed MAP cases to remain pending for 8 to 10 years with no obvious prospect of resolution in the near term." 3

As Glaxosmithkline found to the cost of $\$ 3.1$ billion, MAPs ending in stalemate can be expensive (Green 2006). In that case, which came to a head in 2006, the UK and United States disagreed over which country had the right to the taxable profits from drugs that were developed in the UK, but marketed and distributed in the United States. From the perspective of the UK's tax authority, most of the value was generated by research and development in the UK, while the IRS reportedly took the view that the U.S. affiliate bore all the risk of the venture, and as a result should be compensated for its success. As one commentary on the case argued, "it is becoming increasingly evident that what is needed is some form of binding arbitration requirement, rather than the current quaint 'we'll try to help you out if we can' arrangement" (Green 2006, 3).

Mandatory binding tax treaty arbitration is an institutional innovation that definitively curbs state sovereignty in dispute settlement. Where states cannot reach agreement through a MAP within a specified time limit, either the taxpayer or one of the states involved can refer the disagreement to a panel of independent tax practitioners, whose decision will be binding on both states. The rules vary, but typically each state nominates one or two arbitrators, who then choose the panel chair. Arbitrations take place in secret, and those involved are bound to confidentiality, but all the experienced arbitrators we are aware of are eminent tax lawyers in private practice or academia.

This transnational judicialization is the most pertinent innovation taking global tax governance in a neoliberal, constitutional direction since the 1970s. This is because it makes existing institutions more enforceable for transnational capital, at a supranational level, where previously states could only be held to international tax commitments by their own domestic courts. Certainly, when states faced public and political demands to make multinationals pay more tax, international institutions discouraged them from acting unilaterally. But those institutions predate the neoliberal era of globalization. In contrast, tax 
arbitration is a recent shift that represents a hardening of states' obligations, in the interests of transnational capital.

\section{Fiscal Sovereignty as an Enduring Obstacle}

The emergence of tax arbitration should be seen in the context of states' reluctance to allow supranational institutions to encroach onto their fiscal sovereignty. In contrast, they have been more willing to cede ground to transnational judicial processes in other areas of economic law. There is a clear tension between the neoliberal state's impulse to bind its own hands to protect free markets, and its attachment to its taxing powers. Perhaps most tellingly, taxation is one area in which states of the otherwise highly integrated European Union have been unwilling to pool sovereignty, and they still retain their vetoes to this day. International relations scholarship observes that states are willing to tolerate suboptimal outcomes from international institutions because they are reluctant to cede sovereignty over fiscal policy. For example, Ronen Palan notes that tax havens are an artefact of traditional Westphalian sovereignty norms (Palan 2003). For Thomas Rixen, rules on international taxation "are chosen in such a way as to interfere as little as possible with national tax laws ... The tax treaty regime is built on sovereigntypreserving cooperation" (Rixen 2010).

In the realist tradition, the relationship between taxation and war makes tax sovereignty a key component of statehood itself. In Leviathan, Thomas Hobbes ascribes to the sovereign the right "to levy mony upon the Subjects" to fund the making of war, while for Charles Tilly, tax ultimately underwrote war financing, and was thus essential to the mechanism through which "war made the state" (Hobbes 1994, 134; Tilly 1992, 85). The state's claim to a monopoly over the right to tax led Douglass North to define the state as "an organization with a comparative advantage in violence, extending over a geographic area whose boundaries are determined by its power to tax constituents" (North 1981, 21).

Fiscal sociologists such as Rudolf Goldscheid and Joseph Schumpeter add to this a notion of fiscal contract, a relationship of mutual accountability between state and citizens that emerged when those paying tax revenues demanded the creation of a public financial realm separate from the ruler's private finances (Goldscheid 1958; Schumpeter 1918). Even Jean Bodin, famous for his conception of the absolutist state that could impose its will on all subjects regardless of their consent, found the limit to kingly power in taxation (Wolfe 1968). As Margaret Levi argued, compliance with the state's tax demands is "quasi-voluntary" and relies on a social contract with citizens as well as enforcement threats (Levi 1988). So dominant is this view that many cross-country studies use the tax share of GDP as a proxy for state capacity and autonomy from private elites (Slater, Smith, and Nair
2014). It follows that states will cleave to their taxing powers because they are a key component of both domestic and international sovereignty.

The interests of transnational capital are not, however, diametrically opposed to those of the state that seeks to retain sovereignty. Businesses and other private actors benefit from the ambiguities and inconsistencies between national tax systems created by an emphasis on sovereignty preservation. These gaps and mismatches create manifold opportunities for tax planning, which, along with complexity inherent to transfer pricing and the proliferation of disputes, have spurned a large and well-remunerated international tax advisory profession with a vested interest in maintaining the system as it is (Büttner and Thiemann 2017; Picciotto 2015). The regime also leaves states free to compete using tax rates, exemptions, and other rules.

We understand advocacy for tax arbitration as an attempt to hold onto these benefits, ensuring the regime's ongoing viability and minimizing the attendant costs to businesses. It reinforces tax stability by hardening states' commitments to treaties and transfer pricing rules, but it also mitigates the threat that they will adopt much more integrated tax rules that would close off opportunities for tax avoidance and pressure for tax competition. Yet these same sovereignty-preserving design elements also meant that tax arbitration had to be pursued in incremental steps.

\section{Business Power and Path Dependence}

Slobodian and Gill describe how states have proactively cooperated to create institutions to tie their own hands, rather than merely acquiescing to market discipline. To understand how business power achieves this aim requires moving beyond a structural power framing focused on competition, and indeed Slobodian's account focuses on the influential role of key intellectuals. There are two aspects of international tax institutions that make such an approach especially necessary. To begin with, capital-rich states' preferences in international negotiations are frequently a function of business interests, in combination (or in tension) with a desire to maximize revenue. International cooperation allows them to reconcile capital's desire for a lower effective tax rate with the state's own need for resources, by instead limiting multinationals' overseas tax burdens. This can be seen in their pursuit of bilateral tax treaties with capital-importing countries, the effect of which is to shield their own MNEs from modes of taxation that are not "acceptable," as well as to transfer some of the cost of relieving double taxation onto the fisc of the capital importer (Dagan 2000; Hearson 2021). It can also be seen in the United States' general approach towards multilateral negotiations, in which it seeks to maximize its own ability to tax inbound and outbound capital, while minimizing other states' ability to tax U.S. outbound multinationals and their 
own private citizens' wealth held in the United States (Hakelberg 2020).

Furthermore, the actors negotiating these international tax instruments frequently transcend the state/market boundary. U.S. representatives in international negotiations are drawn on a temporary basis from District of Columbia law firms, where they advise multinationals on how to limit their tax bills. While European countries tend to be represented by career civil servants, it is common for these officials to leave government to become lobbyists and advisers for multinational firms. The OECD Secretariat, too, draws its staff from both public and private sectors. The most influential voices in international tax debates are often those who can speak the language of international tax law, and leverage the experiences of a varied career (Christensen 2019; Picciotto 2015; Seabrooke and Wigan 2016). Members of the transnational policy community on either side of the state/business divide often have more in common than they do with non-specialists from their own constituency (Hearson 2021). In short, business power in international taxation manifests as the instrumental power through which capital influences the development of soft law institutions, as well as the disciplining power of capital markets that encourages their adoption by states as hard law.

The mechanisms of business power take time to bear fruit. But they take longer in international tax cooperation because of the lock-in effect created by regime design choices that date back to the 1920s and 1930s (Rixen 2011). Literature on the international tax regime portrays its institutions as unusually resistant to change. Its sovereignty-preserving design is decentralized, allowing states the freedom to conclude bilateral tax treaties with whomever, and on whatever terms, they prefer. Sovereignty preservation is one of the regime's normative characteristics, weaponized by tax havens when the OECD first tried to curb their harmful tax competition (Sharman 2006). OECD members, as a cartel of capital exporters, have a strong vested interest in maintaining institutions that constrain the taxing powers of countries in capital importing mode, in spite of those institutions' imperfections (Genschel and Rixen 2015).

How then can subversive actors overcome this resistance? There are several "transition paths" that could guide states in such a direction (Woll 2008). First, "subversive" interests with a desire for fundamental reforms, but confronting strong state veto points, can keep up a drumbeat over time that the thing that states want (in this case, to eliminate double taxation while preserving sovereignty) is better achieved by alternative means. Thus, they pledge fealty to the states' goals, disguise their true preference for change, and burrow from within, advocating for new mechanisms layered on top of old ones that will help them achieve their actual goals (Mahoney and Thelen 2010). Such was the experience of leftist community health activists under Brazil's dictatorship, who took advantage of the government's desire for greater penetration into the countryside to drive decentralization and universalization of rural health care (Falleti 2010). Non-state actors can thus appeal to a given regime's purpose and convince states that their fix will serve the original intentions better.

Second, subversives can appeal to values outside of a specific regime purpose. For instance, during the neoliberal period, the idea of bringing market values and disciplines into the state-such as through cost-benefit analysis - has had broad appeal. Indeed, as economies have become more financialized, policymakers and the public increasingly believe that efficiency is a paramount goal, but markets are so complex that their governance must be left to (often private) experts (Johal, Moran, and Williams 2014). Likewise, as gridlock makes dispute resolution through political means more elusive, the reliance placed on legalized and judicialized dispute settlement increases. Such mechanisms are also justified for their efficiency and promotion of the idea of "rule of law" (Abbott et al. 2000; Alter, Hafner-Burton, and Helfer 2019). Reforms that advance economic or legal values that states have internalized are easier to sell.

Third, subversives can emphasize that sovereignty cession is not an "all or nothing" proposition. Sovereignty is a bundle of powers that can be disaggregated and pooled for some functions but not others. It can, for instance, be distinguished by whether it refers to control domestically over borders and internal territory, or to freedom from kinetic or legal coercion by other states (Krasner 2001). Several leading contributions in the tax literature, moreover, distinguish between de facto and de jure sovereignty (Dietsch and Rixen 2014; Rixen 2008: 26-29). Indeed, in practice, the severability and malleability of sovereignty is what has produced a patchwork of power-sharing between federations, confederations, and other international hierarchies (Mcconaughey, Musgrave, and Nexon 2018).

This feature of sovereignty means that nations can preserve their executive and legislative sovereignty, ceding only their judicial sovereignty. This can seem lower stakes and doesn't compete with the prerogatives of the actors that must agree to the change. Indeed, court systems tend to accrete their power-as anti-federalists warned in the United States' own early constitutional debates- "by insensible degrees." This was precisely because judges exercise their power "in cases which arise between individuals, with which the public will not be generally acquainted. One adjudication will form a precedent to the next, and this to a following one [even though] these cases will immediately affect individuals only" (Brutus 1788). This enables a slowmoving but steady march towards judicial review and even judicial supremacy, all from what seem like low-stakes decisions. For instance, the European Court of Justice asserted the (not previously agreed) power of review of 
national court decisions over a $\$ 3$ unpaid electric bill (Alter 2003). Yet, especially when the choice of who has access to the judicial processes is not the executive's to make, outside actors can quickly ramp up the production of legal rules and precedents in ways the initial "agreers" did not expect (Keohane, Moravcsik, and Slaughter 2000).

Indeed, a turn towards the judicial is logical for subversive business interests. It is in businesses' interest to shift the space of contestation into more technocratic, less visible spheres, since politicization can be intensely hostile to capital's interests (Bell and Hindmoor 2013). Resolving disputes through judicialized proceedings in camera is a prime example of what Culpepper (2016) calls "quiet politics.”

\section{Alternative Explanations and the Problem of Timing}

We have argued that the global tax regime of institutions that constrain states in their efforts to tax multinational firms is best seen as an elite project, developed by a community of individuals in government and the private sector. It is also sticky, due to its design features and normative underpinnings. As such, instrumental business power is fundamental to incremental change within the regime, just as it was to its creation.

Before we demonstrate how the emergence of tax arbitration supports this argument, we now briefly consider three alternative hypotheses that, in isolation, are unable to explain the pattern of change. Our purpose here is not to demonstrate that these elements played no role in the process we describe, but that they are insufficient explanations on their own. The rest of the article will demonstrate how our explanation adds to them to create a better fit with the empirical data.

Two of these hypotheses suggest that states adopted tax arbitration as part of an incremental progression in the direction of more sovereignty-constraining commitments by states. The first is the widespread erosion of sovereignty as a norm in economic policy, as part of an ongoing trend towards the legalization and in particular the judicialization of international relations (Abbott et al. 2000; Alter, Hafner-Burton, and Helfer 2019) as well as the emergence of new constitutionalism (Gill 1998). The second is the intensification of competition for FDI, which has created pressure for states to adopt capital-friendly tax policies and international agreements (Barthel and Neumayer 2012; Clausing 2016; Elkins, Guzman, and Simmons 2006).

While the emergence of tax arbitration seems consistent with both these trends, they cannot explain why states' attitudes to tax arbitration at a given time are frequently misaligned with the broader direction of travel in global economic governance. Strong pressure for tax arbitration at the turn of the 1980s produced no results, even though this was a moment when the structural power of capital was strong (Blyth 2002), and the United States would be governed for over a decade by administrations with a procapital economic ideology (Pierson and Hacker 2008; Prasad 2018). For example, the United States began to negotiate bilateral investment treaties that included investor-state arbitration in 1981, and by the mid-1990s it was committed to enforceable arbitration regimes that could be — and were—used against it: the 1993 NAFTA agreement included an investor-state dispute settlement procedure, followed by state-state arbitration through the WTO's dispute settlement understanding in 1995. Yet business advocates of tax arbitration could find no traction until a decade later, in the mid-2000s. They also struggled in the European Union, where sovereignty-constraining cooperation was intensifying overall in the 1970s and 1980s, but an arbitration proposal made in 1976 was kicked into the long grass for over a decade.

Recent events further underline this timing mismatch. The United States insisted on widespread commitments to tax arbitration in OECD negotiations during 2019 and 2020. Yet this was a time when the Trump administration, elected on a platform emphasizing sovereignty over globalization, was actively undermining other arbitration regimes at NAFTA and the WTO to the point of collapse. New agreements subjecting states to arbitration, such as the Trans-Atlantic Trade and Investment Partnership, have also been abandoned since 2016. The principle of tax arbitration was embraced by most OECD states in 2017, in spite of an upsurge in nationalist politics: the UK, which voted to leave the European Union in part over concerns about judicial sovereignty, has been an enthusiastic supporter of tax arbitration. Support for arbitration across the OECD also appears anomalous in the post-financial crisis tax cooperation landscape, which has been characterized by a break from the race to the bottom and an emphasis on limiting tax avoidance and evasion (Christensen and Hearson 2019; Hakelberg and Rixen forthcoming; Mason 2020).

A third explanation is political partisanship, which does not presume a linear trend towards capital-friendly tax policies, expecting them to be supported in the United States by Republican administrations and resisted by Democratic ones (Campbell 2009). This might explain why the pro-free trade Clinton administration was willing to agree to arbitration in two major trade agreements, NAFTA and the WTO, but not to tax arbitration. Yet, as we will demonstrate, the Democrats in Congress in 2006 were if anything more enthusiastic for sovereigntyconstraining arbitration than the Bush administration, and the Obama administration was also an active champion of tax arbitration beyond the commitments it inherited from Bush. Furthermore, many arbitration advocates were Democratic donors.

To solve the timing puzzle, we will focus on how instrumental business power acting against institutional rigidity produced an incremental change. Put simply, it 
took longer for private interests to achieve their objective in tax cooperation because of the normative and formal institutional obstacles that needed to be overcome. Those obstacles dictated a mechanism of incremental change through layering.

\section{The Rise of Tax Arbitration}

In this section, we review the development of international taxation institutions over the last half century, showing how the loosening of capital restrictions at the end of Bretton Woods created tensions that eventually led to the emergence of tax arbitration, through an incremental process. Our account focuses on the United States. This choice reflects its status as the lone "great power" with the ability to instigate - or block — radical change in the institutions of global tax cooperation (Hakelberg 2020). The online appendix gives an historical account of the regime's creation and elaboration from the 1920 s to the 1960 s.

\section{Cracks Emerge in the International Tax Regime}

The early 1970s was the beginning of a period of intense growth in cross-border capital flows, as the Bretton Woods system of fixed exchange rates and capital controls fell apart. This transformation did not only place pressure on the institutions created at the Bretton Woods conference, but also on international tax rules that had been drawn up decades earlier at the League of Nations and inherited by the OECD (Picciotto 1992). In a series of reports, the League's Fiscal Committee had laid the foundations of an enduring regime to tackle the problem of "double taxation" that occurred when multinational investors faced conflicting claims to tax their income from the different countries in which they operated. The League's solution was premised on two key fragmentations. First, rather than a single binding multilateral agreement, international tax rules comprised a network of binding bilateral agreements, standardized through multilateral models. Second, in the eyes of tax authorities, multinational taxpayers were separated into individual entities, each of which was taxed as if it were independent, trading with other parts of the multinational group at arm's length. This is the system known as "transfer pricing". An alternative approach rejected by the League was unitary taxation with formulary apportionment, which would have treated multinationals as holistic entities whose profits were allocated between states according to a formula.

As cross-border capital flows increased, states began to compete to attract mobile capital. Businesses and wealthy individuals exploited tax treaties and transfer pricing techniques to arbitrage between them, moving their income on paper to the jurisdictions in which they faced the lowest taxation. Tax havens-specializing in attracting this capital-began to emerge (Palan 2003). "As an unintended consequence of its institutional setup," argues
Rixen, "the tax regime, which originally only dealt with double tax avoidance, endogenously creates undertaxation" (Rixen 2011, 220).

Yet the regime's design hamstrung states' response: hundreds of bilateral treaties, and a superstructure of soft international and hard national laws built on them, could not easily be dismantled and replaced with a new regime based on different principles. As a senior British tax official wrote, regarding some of the pressures created by early capital account liberalization in the UK, "thirty years of history ... effectively preclude us from taking [another] course. We cannot now go back to square one" (Lord 1967). Furthermore, the major capital-exporting states recognized that the present system, though imperfect, gave them large advantages over capital importers (Genschel and Rixen 2015).

By the end of the decade, calls for reform were growing. Unitary taxation began to proliferate among U.S. states, which began to require "combined reporting" from multinationals so that they could assess their share of global profits with a formula instead of relying on transfer pricing (Picciotto 1992). While blessed by the U.S. Supreme Court, the move irritated foreign governments (Weissman 1983). When the Reagan administration pushed states to accommodate multinationals, subfederal officials testified to Congress that this "may unreasonably restrict state fiscal sovereignty and deprive the states of significant revenue" (U.S. Congress 1984, 16). It was President Clinton who pressured a watering down, such that states are only permitted to use formulary apportionment to sort out tax owed between themselves, not beyond the "water's edge" of the nation state (McNeill 1994).

The work of Palan, Picciotto, and Rixen makes a compelling case that institutional rigidity prevented radical reforms, such as unitary taxation, that might have addressed the tax haven problem. But there was another issue: the bilateral regime was increasingly failing to eliminate double taxation, the function for which it was designed. As capital mobility increased, multinational taxpayers increasingly ran up against gaps in the rules' ability to manage the interface between different countries' tax systems. A European Commission document from 1973 laid out the difficulties created by the growth of multinational companies:

The area of taxation probably best reveals the inadequacy of nationally-devised systems supplemented by bilateral agreements for tackling the phenomen [sic] of the growth of multinational undertakings. The coexistence of different non-harmonized tax systems complicates and even often penalizes the international functioning of an undertaking. (European Commission 1973)

Unitary taxation might have eliminated this problem too, but with that proposal off the table, proposals for transnational tax arbitration began to emerge.

In 1979, the Business and Industry Advisory Committee to the OECD (BIAC, composed of multinational 
companies) expressed its dissatisfaction with the timeconsuming and uncertain nature of existing procedures to resolve tax disputes between states (OECD 1984, para. 36). In the OECD's words, "MNEs expressed the view that no topic was more directly concerned with the entire area of transfer pricing" and that "as things are, taxpayers might be exposed to heavy burdens of tax and vulnerable to arbitrary and capricious pricing adjustments by examining revenue agents" (OECD 1984, para. 25). BIAC's advocacy for mandatory and binding dispute settlement in such cases was echoed in a series of studies and reports published by the World Association of Lawyers of World Peace through Law (1979), International Fiscal Association (1981), and International Chambers of Commerce (1984).

The late 1970s and 1980s would at first sight appear to be an ideal time for such ideas to bear fruit, according to the alternative explanations mentioned earlier. The demise of Bretton Woods had demonstrated that states could no longer ignore the structural power of capital, which had further intensified as cross-border markets and the financial sector expanded. States began pooling sovereignty to facilitate cross-border capital flows. This was perhaps most evident in the European Union, which adopted the European Monetary System in 1979, followed by the Single European Act in 1985. The latter promoted the interests of capital through both liberalized economic policy and pooled political sovereignty, expanding the number of policy areas in which states' vetoes were eliminated. By the end of the decade, both the EU and OECD had adopted instruments promoting capital account liberalization. As for political partisanship, right wing governments in the United States and UK pursued aggressive pro-capital agendas, including the "big bang" in financial services. All the signs were good for arbitration, and indeed, during this time states began negotiations through which they would eventually commit to binding dispute settlement in both trade and investment treaties.

Yet advocates of arbitration in the tax sphere were to draw a blank. The OECD noted the "strength of interest" in the topic among the business community but rejected it on grounds of the "unacceptable surrender of fiscal sovereignty" entailed (OECD 1984, para. 115). Unwilling to adopt either mandatory binding arbitration or unitary taxation, it instead opted for a sticking plaster approach that maximized sovereign discretion: enhancing the semidiplomatic mutual agreement procedure (MAP), a negotiated approach to resolving disagreements over treaty interpretation and transfer pricing rules. Although the role for such a procedure had been foreseen as far back as the League of Nations, it was strengthened and its remit expanded.

In Brussels, the European Commission had identified the double taxation problem in its "Action Programme for Taxation," which sought to promote "tax conditions which would enable the highest possible degree of liberalization in the movement of persons, goods, service and capital and of interpenetration of economies" (European Commission 1975, 2). In 1976 it unsuccessfully proposed a Directive obliging states to submit outstanding cases of double taxation to be resolved through binding arbitration. The Arbitration Directive did not gain support from member states, because enforcement would have ultimately been placed under the jurisdiction of the European Court of Justice (ECJ). A tax lawyer who had followed the EU debates at the time explained the difficulty thus:

The problem with arbitration is you give jurisdiction to decide the tax base away. Some states are extremely squeamish about this. In its heart, in its DNA, you do give authority to decide the assessment away. Some jurisdictions were dead against giving authority to the ECJ. (Interview 9)

It would be well over a decade before the Directive eventually reemerged as a Convention, which states were willing to accept because it fell outside the purview of the ECJ. According to a European Commission official, "the legal form was a political decision made by Member States, which has been based on the collective hesitation to surrender a significant part of their fiscal sovereignty [to the ECJ]" (Schelpe 1995).

The Convention left intact so much sovereign discretion that it was not a success. The lack of procedural obligations created opportunities for obstruction by imposing vexatious penalties, for example, on companies that could be waived in return for not triggering arbitral proceedings. "Actually, it wasn't working at all, because the countries wouldn't let you go in," according to a tax practitioner (Interview 9). As a result, arbitrated disputes within the EU were small in number: tacit knowledge among interviewees and in the industry press suggests as few as four disputes in total by the mid-2010s (Sharon 2012). The initial experiences with arbitrations were slow, messy, and expensive (European Commission 2003; Moses 2010). By the end of 2013, 432 active MAP cases in the EU had passed the two-year time limit at which arbitration proceedings should have been triggered, but only one was in arbitration (European Commission 2014).

Across the Atlantic, U.S. Treasury officials also paid lip service to arbitration while retaining full autonomy. In 1990 they committed to "limited and controlled" arbitration of disputes with Germany, an entirely voluntary approach that "in no way impinges upon the sovereignty of either contracting state" (U.S. Congress 1990, 20). Once triggered, all parties would have to comply with the decision, but both states had to agree to initiate the arbitration in advance, as did the taxpayer. Furthermore, the underlying tax policy or domestic tax law couldn't be at stake. They viewed it as an "experiment ... If it works well in Germany, it may be worth considering in some other 
treaties" (ibid. 39). The U.S. Chamber of Commerce and National Foreign Trade Council (NFTC) endorsed the model, but the latter warned that "we trust that both countries will routinely give their consent to arbitration" (ibid. 51). This proved to be the proposal's Achilles heel, and no U.S.-Germany disputes ever occurred. In 1992, Robin Beran, Corporate Tax Director of Caterpillar Inc., wrote an open letter to the International Tax Counsel of the IRS stating that "multinational corporations who have contended with uncertainty ... need an arbitration requirement as a safeguard to double taxation" (Beran 1992, emphasis added).

\section{The Neoliberal Project Bears Fruit}

By 1995 , most OECD members had taken only tentative steps towards binding tax arbitration, even as they had embraced the principle at the WTO, NAFTA, and in a growing number of investment treaties. The OECD proposed to "analyse again and in more detail" the question of tax arbitration, but it moved at a glacial pace (OECD 1995, 62). A decade later, in 2004, it could only promise more study (OECD 2004). By 2007, a proposal for binding arbitration finally emerged, included in the 2008 revision of the OECD model tax convention. This form of arbitration provided for the "mandatory resolution of unresolved MAP issues," and stipulated that the outcome would be "binding on both Contracting States" (OECD 2007, 5).

The main reason for the change of OECD line was the thawing of the U.S. position. In 2006, the Bush administration had unveiled a proposal for mandatory binding arbitration, initially in treaties with Germany and Belgium. In contrast to the 1990 U.S.-Germany agreement, the proposed rules would prevent either state from vetoing the formation of a board once MAP talks dragged past two years. Instead, the formation of a panel could only be blocked if both states agreed, thereby erasing unilateral foot dragging as a viable tactic. Gone was the technical commentary that the underlying tax policy or domestic tax law couldn't be at issue. Investors were more powerful still: unlike the states, they could block the formation of a board beforehand, and reject its decision once rendered.

Treasury officials predicted that the new provisions could lead to companies making more complaints of double taxation because they would now know the dispute would get resolved" (U.S. Congress 2007, 10). Tax staff for Congress celebrated the provisions as a means of disciplining government, "intended to induce the competent authorities to moderate their positions, including before arbitration proceedings would commence, thus increasing the possibility of a negotiated settlement" (Ibid, 22). The NFTC backed up the assessment: "We think having the arbitration process, if you will, hanging over their heads will lead to better-and more efficient- competent-authority work, which is a fine outcome. And, failing that, the arbitration process is also a fine outcome" (Ibid, 40).

Our interviews and commentary in the industry press highlight two elements that contributed to this change. First, a "subversive" - a tax lawyer from private practice with a history of lobbying on behalf of multinational firms - took on the role of "Director, International" at the IRS in 2000. Interviewees and contemporaneous industry press considered Carol Dunahoo as instrumental in driving the change of position (Interviews 2,4,7; Bell 2007; Turner 2005). Prior to the IRS, Dunahoo worked at PricewaterhouseCoopers, from where she acted on behalf of various U.S. business lobbying groups, including the International Tax Policy Forum-on whose behalf she testified before Congress—and the Electronic Commerce Tax Study Group. Almost as soon as she left the IRS in 2004, she authored a report for the NFTC that advocated tax arbitration among a range of business-friendly tax reforms (National Foreign Trade Council 2005). Her co-author, Mary Bennett, would go on to lead the OECD's adoption of arbitration in its model treaty, as head of its secretariat's Tax Treaties and Transfer Pricing division. As Dunahoo explained:

\footnotetext{
The problem is that the competent authority process is presently the only means of ensuring that countries honor their treaty obligations. And it does not require the competent authorities to reach agreement within a reasonable timeframe on a reasonable basis, or even to agree at all. It provides no recourse, even where one of the countries simply declines to enter into discussions on a case or an issue. There is no mechanism to ensure that the competent authority process - and, therefore, the treatyoperate as intended. (cited in Bell 2004)
}

A second factor in the emergence of the Bush proposal was the sovereignty-preserving design championed by Dunahoo and colleagues, which allowed it to be seen as an incremental development in comparison to the nonbinding arbitration provisions. The new treaties' accompanying guidance stipulated that arbitrators would not produce written awards or provide legal reasoning. Their role was reduced to picking which state's tax law interpretation was correct. This system, called "last best offer" or "baseball" arbitration (based on the procedure used to resolve pay disputes in major league baseball), was designed to get states to put their most considered offers on the table, and to minimize the creation of a body of case law (Park 2001). According to one U.S. tax treaty negotiator, it was after examining the baseball-style approach, with its sovereignty-preserving elements, that the United States became more open to arbitration (Henry Louie, cited in Parillo and Gupta 2015). "It would have been harder to get Congress to approve" a "reasoned opinion" approach to arbitration, stated one former Treasury official (Interview 7). Another former official added that "baseball" arbitration helped because "a whole phase of 
turning the battleship around was getting Congress willing to ratify" (Interview 2).

It is worth noting here that, while this change took place under a Republican administration, it had bipartisan support. Many of the key players in the move towards arbitration-including the leadership of the NFTC_-are Democratic donors. ${ }^{3}$ Moreover, congressional Democrats were pushing Bush's Treasury Department even further down the path to judicialization. In the official Senate report, the Democratic majority on the Senate Finance Committee urged the administration to consider that "in the context of a treaty relationship that is more contentious, providing the arbitration board's decisions with precedential value might be desirable in order to avoid arbitrating the same dispute repeatedly" (U.S. Congress 2007, 7). In the hearings, Sen. Robert Menendez (D-NJ) called for "the possibility of taxpayer participation in the arbitration proceedings" (ibid., 33, 47). The NFTC agreed, praising the suggestion as a way that companies "might have some influence with the tax authorities" (ibid., 47). The bipartisan element is illustrated by the Obama administration's subsequent efforts to promote arbitration as an international norm at the OECD.

As with the earlier non-mandatory arbitration clauses, the innovation of "baseball" arbitration seemed like a small enough step to be palatable to government and Congress, but it left the door open to subsequent layering that would chip away at sovereignty-preserving elements of its design. The layering was mutually reinforcing between Washington, DC, Brussels, and Paris. The U.S. change of policy allowed the OECD to endorse mandatory binding arbitration, but the process it proposed was more judicialized by default, based on the "reasoned opinion" approach. By 2009, the United States had already imported a judicializing innovation from the OECD into its own arbitration proceedings: treaties signed with France and Switzerland that year gave taxpayers limited standing, inviting them to submit their own position papers to arbitration panels, which was not possible under the earlier U.S. provisions.

From 2013 to 2015, the Obama administration supported an agreement on arbitration as part of the G20/OECD Base Erosion and Profit Shifting Initiative (BEPS) project on corporate tax avoidance, which would eventually be implemented by twenty-seven countries in 2017 as part of the BEPS Multilateral Instrument. In 2016, the U.S. Model Convention was updated to include mandatory binding arbitration as the default in U.S. negotiations with all countries.

The incremental progress towards more binding arbitration was further underlined in 2017, when the European Council agreed to replace its Convention with a Directive that has a wider scope and is enforceable in the European Court of Justice, precisely the sacrifice of sovereignty that member states had rejected forty years before. It is the first tax arbitration agreement to require that, at a minimum, decision abstracts be published. The European Commission Communication that paved the way for this change noted ruefully that early design decisions prevented more radical reform: elimination of the transfer pricing system altogether "would eliminate the risk of double taxation in the EU," but because of lock-in of such fundamental design decisions, strengthening the arbitration convention was a necessary second-best solution (European Commission 2015, 11).

This head of steam behind tax arbitration is difficult for alternative explanations, as it coincides with a broader context of economic nationalism that has united leftand right-wing governments behind policies that retain national sovereignty and are often detrimental to capital as a result. The U.S. and UK administrations have aggressively pursued withdrawal from sovereignty-pooling institutions against the preferences of capital, yet have been strong advocates of more tax arbitration. Judicial sovereignty was an explicit theme of the Brexit campaign, while opposition to the TTIP was frequently framed around its investor-state dispute settlement provisions. The Trump administration has specifically targeted the WTO's dispute settlement procedures by refusing to approve new judges.

The direction of travel for tax arbitration is not only an exception in the arbitration sphere, but also for taxation, where it is a lone capital-friendly reform since the financial crisis, among ambitious efforts by the OECD and EU to raise more tax revenue by addressing tax evasion and avoidance by cross-border capital. On the tax evasion side, financial secrecy has been radically curbed through the OECD's Global Forum on Transparency and Exchange of Information, which is backed by the threat of G20 and EU sanctions. It monitors tax havens for their compliance with standards, notably a new system through which bulk data on taxpayers' foreign income is exchanged between jurisdictions. This anti-evasion capability appears to have emboldened governments to increase taxes on capital income (Hakelberg and Rixen forthcoming).

As for tax avoidance, the 2017 arbitration agreement was wrapped up in the OECD's BEPS initiative, triggered primarily by the growing "perception that the domestic and international rules on the taxation of cross-border profits are now broken and that taxes are only paid by the naïe" (OECD 2013, 13). The Obama administration, committed to closing off opportunities for tax avoidance in the U.S. tax code, was initially supportive, but soon found itself fighting a rearguard action against measures targeted primarily at increasing U.S. multinationals' tax payments to other governments (Hakelberg 2020). Business was highly dissatisfied with the initiative, apart from the inclusion of arbitration: the NFTC testified to Congress that it was "politically driven and we believe, appeared to 
be aimed more at raising revenue from U.S.-based multinational corporations (MNEs) rather than other global companies" (U.S. Congress 2015, 56).

By 2019, the global promulgation of tax arbitration provisions beyond the OECD became a priority for U.S. businesses, even as unfinished business from the BEPS project snowballed into a protracted negotiation over new rules to tax the digital economy. A statement from the U.S. Council for International Business set this out:

The OECD should require any country that wishes to be part of the new consensus to adopt mandatory binding arbitration, with peer review, as a minimum standard to resolve any disputes arising as a result of the new rules. (Sample 2020)

They had fully converted the U.S. government, and negotiators let it be known that this position was also a red line for the Trump administration (Bulusu and Ali 2019). Arbitration is now a major fault line in global negotiations, with emerging markets and developing countries continuing to cite sovereignty as their main objection (Johnston 2019; Lewis 2016). Proposals currently under discussion to satisfy U.S. demands would expand arbitration far beyond its tentative steps through baseball arbitration. They would create a new multilateral dispute settlement approach in which affected countries would be bound by the decision of panels whose formation they could not block, and on which not all affecting countries would be able to appoint members. Thus, the direction of travel for the United States, $\mathrm{EU}$, and OECD is clear. In 2019, a group of tax practitioners met in London to celebrate the diffusion of tax arbitration and promote the idea of a permanent tax arbitration tribunal. One experienced arbitrator stated boldly that the proposal would offer more of "what we already see developing: an international common law of tax." 4

\section{Conclusion}

It took four decades since the first concerted efforts by pro-judicialization subversives, but by 2017 mandatory binding tax arbitration had become the norm for international tax cooperation, at least within the OECD. It represents a transfer of fundamental attributes of sovereignty from domestic revenue authorities and courts to private adjudicators. In many of the new clauses, taxpayers have more rights of veto over the process than do states. Indeed, the latest generation of treaties also has a much greater role for non-state actors-with taxpayers allowed in some cases to trigger the proceedings. Looked at from a more practical perspective, the result is a net transfer of revenue from governments (in double taxation cases where they cannot agree among themselves) to multinational taxpayers, who can now force a resolution on them.

It is not only the change in position, but also the timing of the change that we have sought to explain. The period from the late 1970s through the 1990s is usually regarded as the high watermark of neoliberal globalization, in which the Reagan and Thatcher governments recast the political consensus for a generation. Yet even then, a strategy of incremental change was necessary. States were only willing to concede arbitration on very sovereignty-preserving terms, rendering it largely ineffective. In contrast, the period since the financial crisis of 2008 has been characterized in the West by a popular backlash against neoliberal globalization and the failure of capital-friendly judicialization projects such as the Doha Round and the Transatlantic Trade and Investment Partnership, not to mention Brexit. There has also been a public clamor for stronger taxation of the wealthy and multinational companies, which formed the backdrop to major international progress on exchange of tax information, as well as to the BEPS project. Yet it is precisely in this era that tax arbitration, a pro-capital reform, has finally come of age.

As we have argued, the timing difference came about because efforts to promote arbitration took decades to bear fruit. This was successful layering: the new regime is the old regime, with an arbitration scheme on top. "Subversives" encouraged states to adopt their preferred outcome by convincing officials that doing so would make the regime more effective at alleviating double taxation, and that arbitration was a necessary cession of the judicial slice of sovereignty in order to hold on to other dimensions. When sovereignty-preserving arbitration designs failed to resolve the problem, more sovereignty-constraining versions were now just a small step away.

By combining insights from the business power, historical institutionalist, and judicialization literatures, we illuminated some of the concrete, often unobserved, power dynamics that explain unlikely or unexpected shifts in observable policies. If even the long-resistant United States can cede sovereignty over the most sensitive policy area, then we would expect to see ongoing sovereignty cession in other policy areas that are characterized by strong instrumental business power.

Finally, we offer a warning to policymakers-particularly those from developing countries with less capacity to shape the double taxation regime in its new era. As recent literature shows, inequality today leads to cognitive and actual capture of the state and policy discourse today and tomorrow (Boushey 2019; Hertel-Fernandez 2019; Saez and Zucman 2019). While we hope that the OECD's BEPS process will help reduce tax avoidance, it is likely that in doing so it will perpetuate a system that continues to be exploited by MNEs, reducing pressure for a more radical overhaul. As the OECD stated at the project's outset, "what is at stake is the integrity of the corporate income tax" (OECD 2013, 10). Arbitration, too, is a means of shoring up that system. 


\section{Supplementary Materials}

Appendix 1. The Development of the International Tax Regime from the 1920s to 1960s.

Appendix 2: List of Interviews (Numbered) and Informal Conversations.

To view supplementary material for this article, please visit http://doi.org/10.1017/S1537592721000967.

\section{Acknowledgements}

Our thanks go to Todd Allee, Florence Dafe, Henry Farrell, Orfeo Fioretos, Nikhil Kalyanpur, Thomas Rixen, Gabriel Siles-Brügge, Catherine Weaver, and four anonymous reviewers for comments, as well as to participants at annual meetings and workshops at the London School of Economics, Oxford University Centre for Business Taxation, and City, University of London.

\section{Notes}

1 Listed in the online appendix.

2 Morris, William. 2015. "Ref: DISCUSSION DRAFT: OECD BEPS ACTION 14."” On file with authors.

3 Of seventy-nine campaign contributions made by NFTC staff totaling over $\$ 60,000$, seventy-eight were to Democrats. Source: Center for Responsive Politics database.

4 Remark made at "An Evening with Tribute," London, September 9, 2019.

\section{References}

Abbott, Kenneth W., Robert O. Keohane, Andrew Moravcsik, Anne-Marie Slaughter, and Duncan Snidal, 2000. "The Concept of Legalization." International Organization 54(3): 401-19.

Alter, Karen J. 2003. Establishing the Supremacy of European Law. Oxford: Oxford University Press.

Alter, Karen J., Emilie M. Hafner-Burton, and Laurence R. Helfer. 2019. "Theorizing the Judicialization of International Relations." International Studies Quarterly 63(3): 449-63.

Baistrocchi, Eduardo, ed. 2017. A Global Analysis of Tax Treaty Disputes. Cambridge: Cambridge University Press.

Barthel, Fabian, and Eric Neumayer. 2012. "Competing for Scarce Foreign Capital: Spatial Dependence in the Diffusion of Double Taxation Treaties." International Studies Quarterly 56(4): 645-60.

Basinger, Scott J., and Mark Hallerberg. 2004. "Remodeling the Competition for Capital: How Domestic Politics Erases the Race to the Bottom." American Political Science Review 98(2): 261-276.

Bell, Kevin A. 2004. "TNI Interview: Carol A. Dunahoo." Tax Notes International. January 20.

_ 2007 . "U.K., U.S. Tax Treaty Negotiators Favor Arbitration." Tax Notes International, February 15.
Bell, Stephen, and Andrew Hindmoor. 2013. "The Structural Power of Business and the Power of Ideas: The Strange Case of the Australian Mining Tax." New Political Economy 19(3): 470-86.

Beran, Robin D. 1992. "Company Recommends Arbitration Provision in Tax Treaties." Tax Notes, April 21.

Blyth, Mark. 2002. Great Transformations: Economic Ideas and Institutional Change in the Twentieth Century. Cambridge: Cambridge University Press.

Boushey, H. 2019. Unbound: How Inequality Constricts Our Economy and What We Can Do about It. Cambridge, MA: Harvard University Press.

Brutus. 1788. "The Power of the Judiciary, Part IV (Antifederalist Paper No. 82)." New York Journal, March 6.

Bulusu, Siri, and Hamza Ali. 2019. "U.S. Will Use Trade Powers to Deter Unilateral Digital Taxes.” Bloomberg Tax, September 11.

Büttner, Tim, and Matthias Thiemann. 2017. "Breaking Regime Stability? The Politicization of Expertise in the OECD G20 Process on BEPS and the Potential Transformation of International Taxation." Accounting, Economics, and Law: A Convivium 7(1). DOI: https:// doi.org/10.1515/ael-2016-0069.

Campbell, Andrea Louise. 2009. "What Americans Think of Taxes." In The New Fiscal Sociology: Taxation in Comparative and Historical Perspective, ed. Isaac William Martin, Ajay K Mehrotra, and Monica Prasad, 48-67. New York: Cambridge

Christensen, Rasmus Corlin, and Martin Hearson. 2019. "The New Politics of Global Tax Governance: Taking Stock a Decade after the Financial Crisis." Review of International Political Economy 26(5): 1068-88.

Christians, Allison. 2011. "How Nations Share." Indiana Law Journal 87(4): 1407-53.

Clausing, Kimberly. 2016. "The Nature and Practice of Tax Competition." In Global Tax Governance: What Is Wrong with It and How to Fix It, ed. Peter Dietsch and Thomas Rixen, 27-54. Colchester: ECPR Press.

Clayson, Murray, Elizabeth Snodgrass, and Calum Young. 2017. "The Changing Face of International Tax Arbitration." Bloomberg International Tax Blog. Retrieved May 10, 2018 (https://www.bna.com/ changing-face-international-b57982086065/).

Culpepper, Pepper D. 2016. "Capitalism, Institutions, and Power in the Study of Business." Oxford Handbook of Historical Institutionalism, ed. Orfeo Fioretos, Tulia G. Falleti, and Adam Sheingate, 453-466. Oxford: Oxford University Press.

Dagan, Tsilly. 2000. "The Tax Treaties Myth.” New York University Journal of International Law and Politics 32. DOI:10.2139/SSRN.379181

Davis, Christina L. 2009. "Overlapping Institutions in Trade Policy." Perspectives on Politics 7(1): 25-31. 
Dietsch, Peter, and Thomas Rixen. 2014. "Tax Competition and Global Background Justice." Journal of Political Philosophy 22(2): 150-77.

Eden, Lorraine, M. Tina Dacin, and William P Wan. 2001. "Standards across Borders: Crossborder Diffusion of the Arm's Length Standard in North America." Accounting, Organizations and Society 26(1): 1-23.

Elkins, Z., A.T. Guzman, and Beth A. Simmons. 2006. "Competing for Capital: The Diffusion of Bilateral Investment Treaties, 1960-2000." International Organization 60(4): 811-46.

European Commission. 1973. "Multinational Undertakings and Community Regulations. Communication from the Commission to the Council." Bulletin of the European Communities Supplement 15/73 (http://aei.pitt.edu/ 8520/1/8520.pdf).

- 1975. "Action Programme for Taxation.

Communication from the Commission to the Council." (https://eur-lex.europa.eu/legal-content/ EN/TXT/PDF/?uri=CELEX:51975DC0391\&rid=3).

_ 2003. "Draft Summary Record of the Third Meeting of the EU Joint Transfer Pricing Forum Held in Brussels on 2nd April 2003.” Doc: JTPF/007/2003/ EN. (https://ec.europa.eu/taxation_customs/sites/ taxation/files/docs/body/minutes02apr_en.pdf).

—. 2014. "Statistics on Pending Mutual Agreement Procedures (MAPs) under the Arbitration Convention at the End of 2013." (http://ec.europa.eu/taxation_ customs/sites/taxation/files/resources/documents/ taxation/company_tax/transfer_pricing/forum/ jtpf/2014/jtpf_008_2014_en.pdf).

_ 2015. "A Fair and Efficient Corporate Tax System in the European Union: 5 Key Areas for Action." (https://eur-lex.europa.eu/legal-content/EN/TXT/ $\mathrm{PDF}$ /?uri=CELEX:52015DC0302\&from=EN).

Falleti, Tulia G. 2010. "Infiltrating the State: The Evolution of Health Care Reforms in Brazil, 1964-88." In Explaining Institutional Change: Ambiguity, Agency, and Power, ed. James Mahoney and Kathleen Thelen, 38-62. Cambridge: Cambridge University Press.

French Tax Administration. 2017. "Mutual Agreement Procedure." impots.gouv.fr. Retrieved July 10, 2020 (https://www.impots.gouv.fr/portail/internationalparticulier/mutual-agreement-procedure).

Genschel, Philipp, and Thomas Rixen. 2015. "Settling and Unsettling the Transnational Legal Order of International Taxation.” In Transnational Legal Orders, ed. Terence C. Halliday and Gregory Shaffer, 154-184. Cambridge: Cambridge University Press.

Gill, Stephen. 1998. "New Constitutionalism, Democratisation and Global Political Economy." Pacifica Review: Peace, Security \& Global Change 10(1): 23-38.

Gill, Stephen, and A. Claire Cutler. 2014. "New Constitutionalism and World Order." In New
Constitutionalism and World Order, ed. Stephen Gill and A. Claire Cutler, 1-22. Cambridge: Cambridge University Press.

Goldscheid, Rudolf. 1958. "A Sociological Approach to Problems of Public Finance." In Classics in the Theory of Public Finance, ed. Richard A Musgrave and Alan T Peacock, 202-13. London: Palgrave Macmillan.

Green, Gareth. 2006. "The UK. Reaction to the Glaxo Case." Tax Planning International: Transfer Pricing, November.

Hakelberg, Lukas. 2020. The Hypocritical Hegemon: How the United States Shapes Global Rules against Tax Evasion and Avoidance. Ithaca, NY: Cornell University Press.

Hakelberg, Lukas, and Thomas Rixen. Forthcoming. "Is Neoliberalism Still Spreading? The Impact of International Cooperation on Capital Taxation." Review of International Political Economy.

Hearson, Martin. 2021. Imposing Standards: The NorthSouth Dimension to Global Tax Politics. Ithaca, NY: Cornell University Press.

Hertel-Fernandez, Alexander. 2019. State Capture: How Conservative Activists, Big Businesses, and Wealthy Donors Reshaped the American States-and the Nation. Oxford: Oxford University Press.

Hobbes, Thomas. 1994. Leviathan: With Selected Variants from the Latin Edition of 1668. Ed. Edwin Curley. Cambridge, MA: Hackett Publishing.

Hyde, Ian, and Robert Thomas. 2016. "Tax Dispute Resolution through Mandatory Binding Arbitration." Tax Journal, July 22.

IMF/OECD. 2017. Tax Certainty: OECD/IMF Report to the G20 Finance Ministers. (https://www.oecd.org/tax/ tax-policy/tax-certainty-report-oecd-imf-report-g20finance-ministers-march-2017.pdf).

Jensen, Nathan M., and René Lindstadt. 2012. "Leaning Right and Learning from the Left: Diffusion of Corporate Tax Policy across Borders." Comparative Political Studies 45(3): 283-311.

Johal, Sukhdev, Michael Moran, and Karel Williams. 2014. "Power, Politics and the City of London after the Great Financial Crisis." Government and Opposition 49 (3): 400-25.

Johnston, Stephanie Soong. 2019. "Certainty at Core of Digital Proposal, OECD Tax Chief Says." Tax Notes. September 23.

Keohane, Robert O., Andrew Moravcsik, and Anne-Marie Slaughter. 2000. "Legalized Dispute Resolution: Interstate and Transnational." International Organization 54(3): 457-88.

Krasner, Stephen D. 2001. "Rethinking the Sovereign State Model." Review of International Studies 27(5): 17-42.

Levi, Margaret. 1988. Of Rule and Revenue. Berkeley: University of California Press.

Lewis, Alexander. 2016. "India Cites Sovereignty Concerns on Binding Arbitration." Tax Notes. December 12. 
Lord, Alan J. 1967. “Memo, Inland Revenue.” National Archives (Foreign Commonwealth Office FCO59/1459). London.

Maffini, Giorgia, ed. 2015. Business Taxation under the Coalition Government. Oxford: Oxford University Centre for Business Taxation.

Mahoney, James, and Kathleen Thelen. 2010. Explaining Institutional Change: Ambiguity, Agency, and Power. Cambridge: Cambridge University Press.

Mason, Ruth. 2020. "The Transformation of International Tax." American Journal of International Law 114(3): 353-402.

Mcconaughey, Meghan, Paul Musgrave, and Daniel H. Nexon. 2018. "Beyond Anarchy: Logics of Political Organization, Hierarchy, and International Structure." International Theory 10(2): 181-218.

McNeill, Bronwyn J.F. 1994. "California's Recent Legislation on Unitary Taxation and Barclay's Bank PLC v. Franchise Tax Boards of California." Tax Lawyer 48(1): 231-53.

Moses, Molly. 2010. "Practitioner Describes Three-Year Arbitration Over Change of Method Under EU Convention." Transfer Pricing Report 19(11): 652-54.

National Foreign Trade Council. 2005. Towards a U.S. Tax Treaty Policy for the Future: Issues and Recommendations. Washington, DC: National Foreign Trade Council

North, Douglass C. 1981. Structure and Change in Economic History. New York: Norton.

OECD. 1984. Transfer Pricing and Multinational Enterprises Three Taxation Issues. Paris: OECD Publishing.

- 1995. Transfer Pricing Guidelines for Multinational Enterprises and Tax Administrations. Paris: OECD Publishing.

- 2004. Improving the Process for Resolving International Tax Disputes. Paris: OECD Publishing.

- 2007. Improving Mechanisms for the Resolution of Tax Treaty Disputes. Paris: OECD Publishing.

—. 2013. Addressing Base Erosion and Profit Shifting. Paris: OECD Publishing.

— 2020. Mutual Agreement Procedure Statistics for 2019. Paris: OECD Publishing.

Palan, Ronen. 2003. The Offshore World: Sovereign Markets, Virtual Places, and Nomad Millionaires. Ithaca, NY: Cornell University Press.

Parillo, Kristen A., and Ajay Gupta. 2015. "Business Sector Decries OECD's Lack of Support for Arbitration.” Tax Notes, January 26.

Park, William W. 2001. "Income Tax Treaty Arbitration." George Mason Law Review 10(4): 803-74.

Picciotto, Sol. 1992. International Business Taxation: A Study in the Internationalization of Business Regulation. London: Weidenfeld \& Nicolson.
2015. "Indeterminacy, Complexity, Technocracy and the Reform of International Corporate Taxation." Social \& Legal Studies 24(2): 165-84.

Pierson, Paul, and Jacob S. Hacker. 2008. Off Center: The Republican Revolution and the Erosion of American Democracy. New Haven, CT: Yale University Press.

Plümper, Thomas, Vera E. Troeger, and Hannes Winner. 2009. "Why Is There No Race to the Bottom in Capital Taxation?” International Studies Quarterly 53(3): $761-86$.

Prasad, Monica. 2018. Starving the Beast: Ronald Reagan and the Tax Cut Revolution. New York: Russell Sage Foundation.

Rixen, Thomas. 2008. The Political Economy of International Tax Governance. New York: Palgrave Macmillan.

_. 2010. "Bilateralism or Multilateralism? The Political Economy of Avoiding International Double Taxation." European Journal of International Relations 16(4): 589-614.

- 2011. "From Double Tax Avoidance to Tax Competition: Explaining the Institutional Trajectory of International Tax Governance." Review of International Political Economy 18(2): 197-227.

Saez, E., and G. Zucman. 2019. The Triumph of Injustice: How the Rich Dodge Taxes and How to Make Them Pay. New York: Norton.

Sample, William J. 2020. "USCIB Comments on the OECD Public Consultation Document on Global Anti-Base Erosion Proposal ('GloBE') Pillar Two.” Tax Notes, March 30.

Schelpe, Dirk. 1995. "The Arbitration Convention: Its Origin, Its Opportunities and Its Weaknesses." EC Tax Review 4(2): 68-77.

Schneiderman, David. 2000. "Investment Rules and the New Constitutionalism." Law \& Social Inquiry 25(3): 757-87.

Schumpeter, Joseph. 1991 [1918]. "The Crisis of the Tax State." In Joseph A. Schumpeter: The Economics and Sociology of Capitalism, ed. Richard A. Swedberg, 99-140. Princeton, NJ: Princeton University Press.

Seabrooke, Leonard, and Duncan Wigan. 2016. "Powering Ideas through Expertise: Professionals in Global Tax Battles." Journal of European Public Policy 23(3): 357-74.

Sharman, J. C. 2006. Havens in a Storm: The Struggle for Global Tax Regulation. Ithaca, NY: Cornell University Press.

Sharon, Craig A. 2012. "Treaty Arbitration: Where Art Thou?" Tax Management International Journal 91-95. (https://www.morganlewis.com/-/media/files/docs/ archive/treaty-arbitration-where-art-thou_6892pdf.pdf).

Slater, Dan, Benjamin Smith, and Gautam Nair. 2014. "Economic Origins of Democratic Breakdown? The 
Redistributive Model and the Postcolonial State.” Perspectives on Politics 12(2): 353-74.

Slobodian, Quinn. 2018. Globalists: The End of Empire and the Birth of Neoliberalism. Cambridge, MA: Harvard University Press.

Swank, Duane. 2006. "Tax Policy in an Era of Internationalization: Explaining the Spread of Neoliberalism." International Organization 60(4): 847-82.

Tilly, Charles. 1992. Coercion, Capital, and European States, A.D.990-1990. Cambridge, MA: Blackwell.

Tucker, Todd N. 2018. Judge Knot: Politics and Development in International Investment Law. London: Anthem Press.

Turner, Geoffrey S. 2005. “Canada-U.S. Competent Authority MOU: First Steps to Mandatory Arbitration?" Tax Notes International. September 28.

U.S. Congress. House. 2015. The OECD Base Erosion and Profit Shifting (BEPS) Project. Hearing before the Subcommittee on Tax Policy of the Committee on Ways and Means. 114th Cong., 1st sess., December 1. U.S. Government Publishing Office.

U.S. Congress. Senate. 1984. Unitary Tax: Hearing before the Subcommittee on International Economic Policy of the Committee on Foreign Relations. 98th Cong., 2nd sess., September 20. U.S. Government Publishing Office.

1990. Pending Bilateral Tax Treaties and OECD

Tax Convention. Hearing before the Committee on

Foreign Relations. 101st Cong., 2nd sess., June 14. U.S. Government Publishing Office.

- 2007. Treaties. Hearing before the Committee on Foreign Relations. 110th Cong., 1st sess., July 17. U.S. Government Publishing Office.

Vaughan, Michael. 2019. "Scale Shift in International Tax Justice: Comparing the UK and Australia from 2008 to 2016." Social Movement Studies 18(6): 735-53.

Weissman, George H. 1983. "Unitary Taxation: Its History and Recent Supreme Court Treatment." Albany Law Review 48(1): 48-108.

Williamson, John. 1990. "What Washington Means by Policy Reform.” In Latin American Adjustment: How Much Has Happened?, ed. John Williamson.

Washington, DC: Institute for International Economics.

Wolfe, Martin. 1968. "Jean Bodin on Taxes: The Sovereignty-Taxes Paradox." Political Science Quarterly 83(2): 268-84.

Woll, Cornelia. 2008. Firm Interests: How Governments Shape Business Lobbying on Global Trade. Ithaca, NY: Cornell University Press. 